\title{
Reelin Proteolysis Affects Signaling Related to Normal Synapse Function and Neurodegeneration
}

\author{
April L. Lussier ${ }^{1}$, Edwin J. Weeber ${ }^{1}$ and G. William Rebeck ${ }^{2 *}$ \\ ${ }^{1}$ Department of Molecular Pharmacology and Physiology, USF Health Byrd Alzheimer's Disease Institute, University of South \\ Florida, Tampa, FL, USA, ${ }^{2}$ Department of Neuroscience, Georgetown University, Washington, DC, USA
}

Reelin is a neurodevelopmental protein important in adult synaptic plasticity and learning and memory. Recent evidence points to the importance for Reelin proteolysis in normal signaling and in cognitive function. Support for the dysfunction of Reelin proteolysis in neurodegeneration and cognitive dysfunction comes from postmortem analysis of Alzheimer's diseases (AD) tissues including cerebral spinal fluid (CSF), showing that levels of Reelin fragments are altered in AD compared to control. Potential key proteases involved in Reelin proteolysis have recently been defined, identifying processes that could be altered in neurodegeneration. Introduction of full-length Reelin and its proteolytic fragments into several mouse models of neurodegeneration and neuropsychiatric disorders quickly promote learning and memory. These findings support a role for Reelin in learning and memory and suggest further understanding of these processes are important to harness the potential of this pathway in treating cognitive symptoms in

\section{OPEN ACCESS}

Edited by: Adalberto Merighi, University of Turin, Italy

Reviewed by: Oliver Von Bohlen Und Halbach, Universitätsmedizin Greifswald,

Germany

Romain Goutagny, Centre National de la Recherche Scientifique, France

*Correspondence:

G. William Rebeck Bill.Rebeck@georgetown.edu

Received: 15 January 2016 Accepted: 11 March 2016 Published: 29 March 2016

Citation:

Lussier AL, Weeber EJ and Rebeck GW (2016) Reelin Proteolysis Affects Signaling Related to Normal

Synapse Function and Neurodegeneration.

Front. Cell. Neurosci. 10:75. doi: 10.3389/fncel.2016.00075 neuropsychiatric and neurodegenerative diseases.

Keywords: Reelin, Alzheimer's disease, neurodegeneration, proteolysis, learning and memory

Neurodegenerative diseases are characterized by the progressive loss of synapses and neurons, accounting for cognitive deterioration. One molecular pathway that is well characterized in playing a role in adult synaptic plasticity and learning and memory is the Reelin signaling pathway (Weeber et al., 2002; Chen et al., 2005; Qiu et al., 2006a,b; Qiu and Weeber, 2007; Rogers et al., 2011). Reelin is also involved in a number of neurodegenerative and neuropsychiatric disorders presenting with cognitive deficits, including schizophrenia (Guidotti et al., 2000; Chen et al., 2002; Fatemi, 2005; Torrey et al., 2005), bipolar disorder (Fatemi et al., 2000; Torrey et al., 2005), depression (Knable et al., 2004; Lussier et al., 2009, 2011, 2013a,b; Fenton et al., 2015), epilepsy (Fournier et al., 2010; Haas and Frotscher, 2010; Dutta et al., 2011) and autism (Fatemi et al., 2005). Furthermore, Reelin signal transduction pathways appear to be particularly vulnerable in Alzheimer's disease (AD), potentially contributing to its pathogenesis (Hoe et al., 2006; Hoareau et al., 2008). Thus, a better understanding of Reelin signaling could be useful in developing therapies against synaptic and neuronal loss in a number of conditions.

\section{REELIN IN DEVELOPMENT}

Reelin is an extracellular matrix protein important in brain development during embryogenesis (for detailed reviews, see Lambert de Rouvroit et al., 1999; Rice and Curran, 2001; Tissir and Goffinet, 2003). During development Reelin is expressed by Cajal-Retzius cells 
in the hippocampus and cortex and granule cells in the cerebellum (Ogawa et al., 1995; Del Río et al., 1997; Frotscher, 1998; Hirota et al., 2015). In the adult brain GABAergic interneurons in the cortex and hippocampus secrete Reelin (Alcantara et al., 1998; Pesold et al., 1998). Much of what we know about the Reelin signaling pathway in development comes from mouse models that have knock-down or overexpression of critical proteins in the pathway: Reelin, lipoprotein receptors, and Disabled-1 (Dab1; Howell et al., 1997b; Hiesberger et al., 1999; Trommsdorff et al., 1999; Beffert et al., 2002; Drakew et al., 2002; Weeber et al., 2002; Qiu et al., 2006a; Pujadas et al., 2010, 2014; Teixeira et al., 2011; Trotter et al., 2013; Lane-Donovan et al., 2015).

\section{REELIN SIGNALING PATHWAY}

Once Reelin is secreted by GABAergic interneurons into the extracellular space it binds to the lipoprotein receptors, verylow-density lipoprotein receptor (VLDLR) and Apolipoprotein receptor 2 (ApoER2; D’Arcangelo et al., 1999; Weeber et al., 2002; Herz and Chen, 2006; Figure 1). Ligand interactions lead to receptor dimerization and tyrosine phosphorylation of the downstream intracellular adaptor protein Dab1 (Howell et al., 1997a; D’Arcangelo et al., 1999; Hiesberger et al., 1999; Strasser et al., 2004; Herz and Chen, 2006; Trotter et al., 2013, 2014; Divekar et al., 2014). Dab1 phosphorylation activates Src family tyrosine kinases (SFK), such as Fyn, which phosphorylates $\mathrm{N}$-methyl-D-aspartate (NMDA) receptors allowing increases in $\mathrm{Ca}^{2+}$ influx (Chen et al., 2005). Enhancement in $\mathrm{Ca}^{2+}$ influx allows for maturation of NMDA receptors from the NR2B to NR2A receptor subtype, increased membrane $\alpha$-amino-3hydroxy-5-methyl-4-isoxazolepropionic acid (AMPA) receptor insertion, and can contribute to the induction and enhancement of long-term potentiation (LTP; Weeber et al., 2002; Beffert et al., 2005; Chen et al., 2005; Herz and Chen, 2006; Qiu et al., 2006b; Qiu and Weeber, 2007). In addition, Dab1-induced phosphorylation also can activate Phosphatidylinositol-3-kinase $(\mathrm{PI} 3 \mathrm{~K})$ and protein kinase $\mathrm{B}(\mathrm{PKB} / \mathrm{Akt})$ which then causes Glycogen synthase kinase 3 beta (GSK3 $\beta$ ) inhibition (Beffert et al., 2002), in turn suppressing tau hyperphosphorylation (Ohkubo et al., 2003).

As Reelin positive cells are found in highest numbers in the CA1 stratum lacunosum and hilus, they are in prime locations to influence learning and memory, and neurogenesis, respectively. Indeed, Reelin has been shown to enhance synaptic plasticity and learning and memory (Weeber et al., 2002; Herz and Chen, 2006; Rogers and Weeber, 2008), as well as alter migration of adult born neurons (Zhao et al., 2007; Pujadas et al., 2010; Teixeira et al., 2012). In the hippocampus, extracellular Reelin accumulates in the stratum lacunosum (Pesold et al., 1999; Lussier et al., 2009) which makes it in a prime location to influence synaptic activity in the CA1 (Weeber et al., 2002; Herz and Chen, 2006;

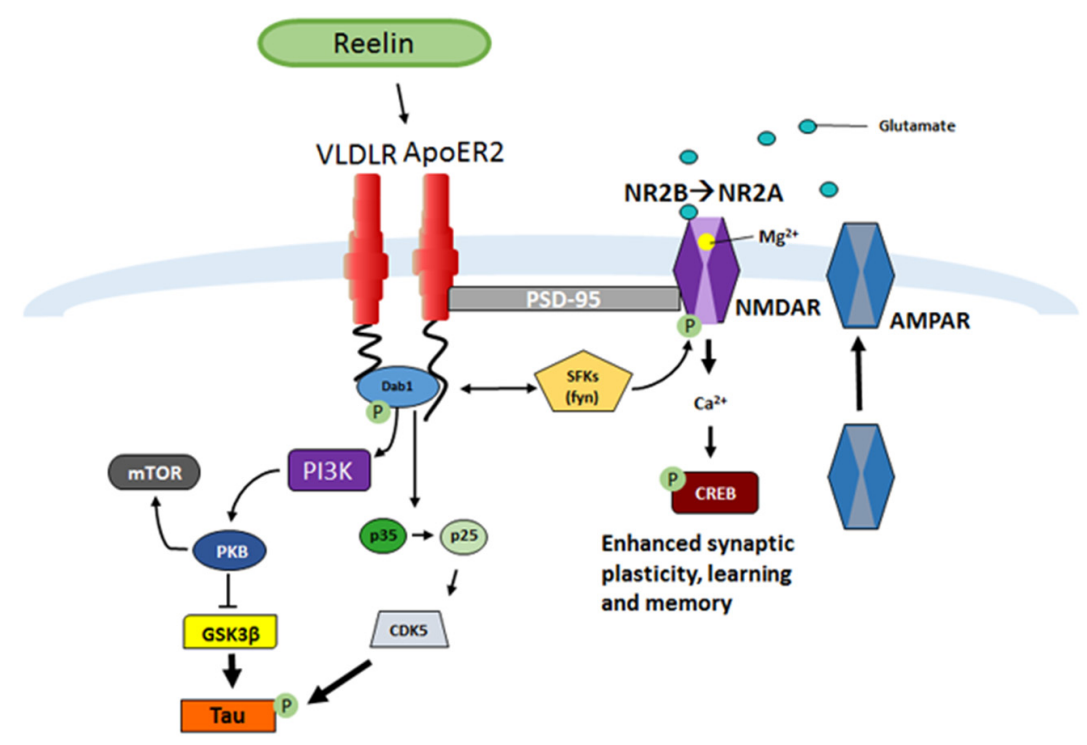

FIGURE 1 | Reelin signaling pathway in adult synaptic plasticity. Reelin binds to the lipoprotein receptors apolipoprotein receptor 2 (ApoER2) and very-low-density lipoprotein receptor (VLDLR) which causes receptor clustering and the src family tyrosine kinases (SFK) tyrosine phosphorylation of the intracellular adaptor protein Disabled-1 (Dab1), which results in the phosphorylation of N-methyl-D-aspartate receptor (NMDAR; D'Arcangelo et al., 1997, 1999; Weeber et al., 2002; Niu et al., 2004; Beffert et al., 2005; Chen et al., 2005; Qiu et al., 2006b; Qiu and Weeber, 2007; Burrell et al., 2014; Divekar et al., 2014). A subsequent increase in calcium influx leads to depolarization of the post-synaptic membrane and $\alpha$-amino-3-hydroxy-5-methyl-4-isoxazolepropionic acid receptor (AMPAR) insertion (Weeber et al., 2002; Qiu et al., 2006b; Qiu and Weeber, 2007). A consequence of the increase in Ca ${ }^{2+}$ influx and depolarization of the cell is increased CREB phosphorylation and protein synthesis, which ultimately results in increased synaptic plasticity and learning and memory (Niu et al., 2008; Rogers et al., 2011, 2013). Another result of Dab1 phosphorylation is activation of phosphatidylinositol-3-kinase (PI3K), protein kinase B (PKB/Akt), and modulation of Glycogen synthase kinase 3 beta (GSK33), which inhibits Tau phosphorylation (Beffert et al., 2002). Phosphorylation of Dab1 also regulates the conversion of p35 to p25 and results in activation of CDK5, also responsible for Tau phosphorylation (Beffert et al., 2004). 
Rogers and Weeber, 2008). Endogenous cleavage of Reelin in these regions may be used to regulate Reelin's effects on these processes.

\section{REELIN PROCESSING}

Reelin signaling may not be driven by the simple production and release of Reelin from interneurons, as with neuropeptides or small molecule transmitters, but it may be regulated by the directed proteolysis of sequestered, full length, extracellular Reelin. Reelin has been shown to have two main sites of cleavage, between EGF-like repeats 2-3 (R2-3) and repeats 6-7 (R6-7; Jossin et al., 2004; Figure 2). These cleavage sites result in five major fragments that can be found in the adult and developing brain (Jossin et al., 2007; Krstic et al., 2012; Trotter et al., 2014). The middle R3-6 fragment interacts with the VLDLR and ApoER2 and is considered the fragment that is involved in initiating the downstream signaling of the Reelin cascade (Jossin et al., 2004). Our laboratory (Trotter et al., 2014) and others (Nagy et al., 2006; Nogi et al., 2006; Nakano et al., 2007; Hisanaga et al., 2012; Krstic et al., 2012) have attempted to identify Reelin-cleaving enzymes, such as the serine protease tissue plasminogen activator (tPA), matrix metalloproteinases (MMP), and a disintegrin and metalloproteinase with thrombospondin motifs (ADAMTS), and the functional role of this proteolytic processing.

We have recently identified one mechanism for the normal processing of extracellular Reelin, through the effects of the serine protease tPA in the brain (Trotter et al., 2014). The activity-dependent proteolysis of Reelin between R6 and R7 in wild-type mice was not seen in tPA KO mice, supporting

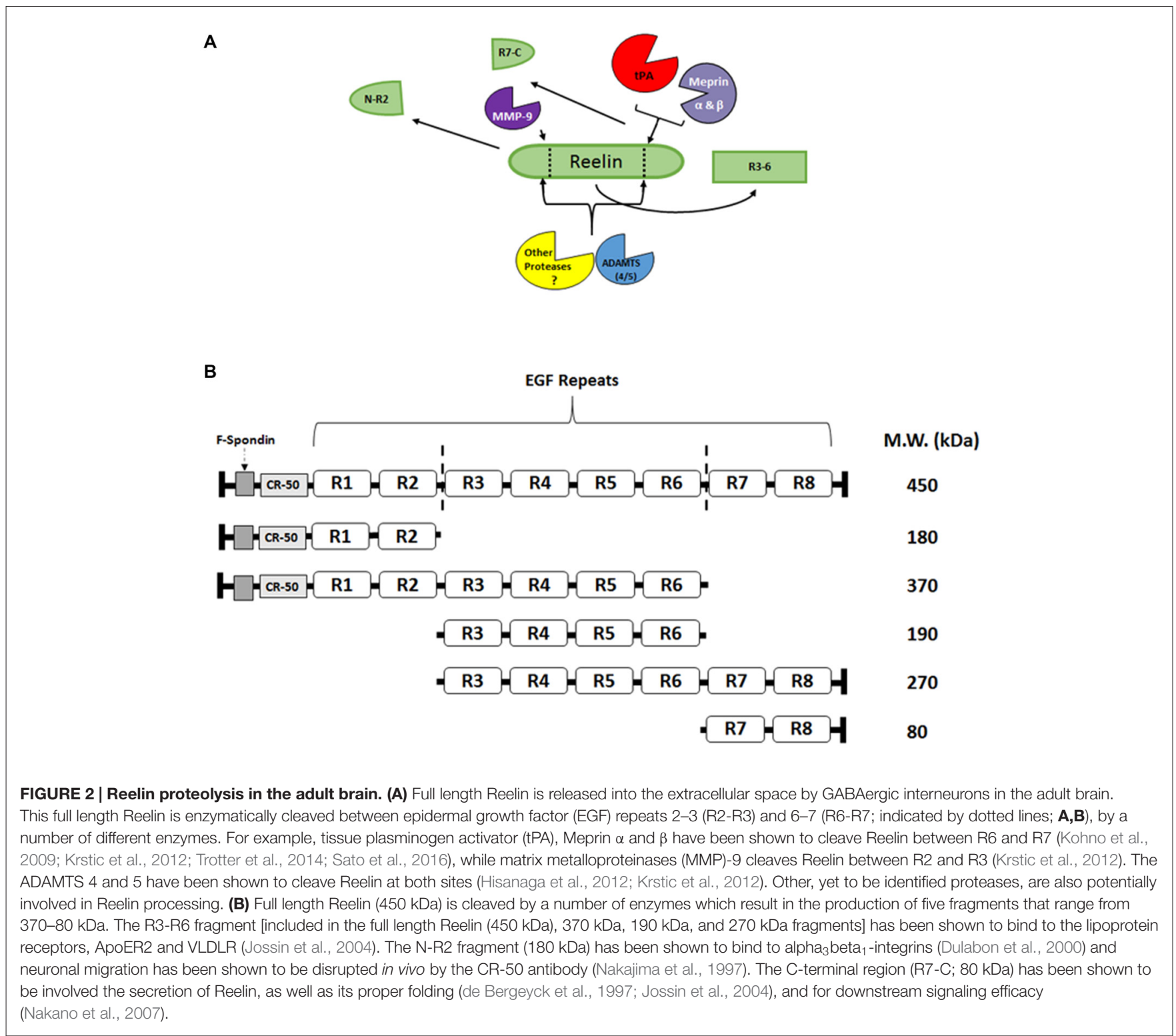


a role of this protease in NMDAR-independent LTP induced cleavage of Reelin (Trotter et al., 2014). In cell culture, Reelin cleavage between R6-7 by tPA was blocked by serpin E1 inhibitor (Krstic et al., 2012). Our cell-free conditions in which we incubated tPA with Reelin for $45 \mathrm{~min}$ also produced increased the N-R6 fragment $(370 \mathrm{kDa})$, which was blocked with Plasminogen activator inhibitor (PAI-1; serpin E1) and diisoporpyl fluorophosphates (a serine protease inhibitor), but not blocked by Aprotinin or CR-50 (an antibody that binds in the N-terminal region of Reelin; D'Arcangelo et al., 1997; Trotter et al., 2014). Similarly, metalloproteases meprin $\alpha$ and $\beta$ cleave Reelin between the R6 and R7 repeats (Sato et al., 2016). However, neither tPA knock-out mice (Trotter et al., 2014) nor meprin $\beta$ knock-out mice (Sato et al., 2016) demonstrate differences in basal levels of full length Reelin or Reelin fragments, suggesting that combinations of proteases are involved in constitutive Reelin levels and proteolysis. Furthermore, Reelin proteolysis may be important in activitydependent or pathological conditions.

Much of what is known about signaling abilities of specific Reelin domains comes from research on the canonical Reelinlipoprotein-Dab1 pathway (Figure 1). In support of the importance of the middle R3-6 fragment in lipoprotein receptor binding, cleavage within the R3 repeat has recently been shown to decrease Dab1 phosphorylation (Kohno et al., 2009; Koie et al., 2014). However, the other fragments have also been suggested to be vital for normal Reelin signaling. For example, the N-R2 fragment has been shown to bind to alpha beta $_{1}$ integrins (Dulabon et al., 2000) and the CR-50 antibody can disrupt in vivo neuronal migration (Nakajima et al., 1997). The C-terminal region (R7-C) has been suggested to be involved in Reelin secretion, folding (de Bergeyck et al., 1997; Jossin et al., 2004), and signaling efficacy (Nakano et al., 2007), although no known receptors have been identified for $\mathrm{R} 7-\mathrm{C}$ binding. Recently, Kohno et al. (2015), have shown that the C-terminal region is critical in postnatal cerebral cortex development but not in embryonic stages. Further research is needed to fully elucidate the importance of these specific fragments in normal and pathological conditions.

\section{REELIN AND NEUROPSYCHIATRIC/ NEURODEGENERATIVE DISORDERS}

Support for the role of Reelin proteolysis in human disease has been found in both neuropsychiatric and neurodegenerative disorders. For example, the N-R2 fragment is increased in AD and frontotemporal dementia patients when compared to nondemented patients (Sáez-Valero et al., 2003; Botella-López et al., 2006). In patients with confirmed diagnosis for depression and bipolar disorder, the N-R2 fragment is found to be decreased in blood samples, while for schizophrenia patients the N-R6 fragment is increased (Fatemi et al., 2001). Reelin may also play a role in seizure control: epilepsy models have altered Reelin processing (Tinnes et al., 2011, 2013; Kaneko et al., 2016), which may be MMP-dependent. These differences in Reelin fragment levels point to an importance in Reelin levels and proteolytic dysfunction in disease states.

\section{REELIN AND AD PATHOETIOLOGY}

In $\mathrm{AD}$, loss of synapses and neurons is accompanied neuropathologically by amyloid deposits composed of the Amyloid beta $(\mathrm{A} \beta)$ peptide, and neurofibrillary tangles composed of modified versions of the tau protein (Trojanowski and Lee, 2002; Schellenberg and Montine, 2012; Sheng et al., 2012). Exogenous $A \beta$ application and endogenous $A \beta$ aggregates block various forms of synaptic plasticity and inhibit memory formation and retrieval (Klyubin et al., 2005; Selkoe, 2008; Talantova et al., 2013). Hyperphosphorylated forms of tau are also associated with the disruption of synaptic plasticity, learning and memory (Trojanowski and Lee, 2002; Santacruz et al., 2005; Lasagna-Reeves et al., 2011, 2012; Shipton et al., 2011). Altered Reelin signaling has been linked to AD through analyses of human brain samples (Herring et al., 2012; Notter and Knuesel, 2013), and animal models connecting Reelin to the processes of amyloid accumulation (Chin et al., 2007; Kocherhans et al., 2010; Pujadas et al., 2014) and to tau phosphorylation (Ohkubo et al., 2003; Herz and Chen, 2006; Kocherhans et al., 2010; Cuchillo-Ibáñez et al., 2013). In addition, Reelin signaling has been associated with human AD synaptic dysfunction in a non-targeted transcriptomic approach (Karim et al., 2014), and the Reelin gene was associated with $\mathrm{AD}$ pathological findings in elderly controls in a nontargeted genomic approach (Kramer et al., 2011). Finally, two of the strongest genetic risk factors for $\mathrm{AD}$, Apolipoprotein $\mathrm{E}$ (APOE) and clusterin (APOJ), encode proteins that bind to the Reelin receptors (Reddy et al., 2011; Tapia-González et al., 2011).

These lines of research have led to the investigation of possible mechanisms for how Reelin could specifically affect AD. Reelin may modify amyloid levels by directly interacting with amyloid precursor protein (APP; Hoe et al., 2009) or altering APP metabolism to decrease the generation $\mathrm{A} \beta$ (Rice et al., 2013; Pujadas et al., 2014). Reelin also causes GSK3 $\beta$ inhibition (Beffert et al., 2002), which suppresses tau hyperphosphorylation (Ohkubo et al., 2003). In mouse models of $\mathrm{AD}$, overexpressing Reelin prevented $\mathrm{AD}$ pathological changes (Pujadas et al., 2014), and lowering levels of Reelin accelerated $\mathrm{A} \beta$ deposition and the synaptic dysfunction caused by the presence of amyloid (Kocherhans et al., 2010; Lane-Donovan et al., 2015). In addition to these effects on the neuropathologic accumulations in AD brain, several lines of evidence suggest that Reelin and $\mathrm{A} \beta$ have antagonistic effects on neuronal survival and signaling. These findings include reduction of Reelin and Reelin signaling in an AD mouse model (Mota et al., 2014), electrophysiological measures of Reelin and $A \beta$ effects on hippocampal brain slices (Durakoglugil et al., 2009), and behavioral studies in $\mathrm{AD}$ mouse models with altered levels of Reelin (Pujadas et al., 2010; Lane-Donovan et al., 2015).

\section{REELIN AS A THERAPEUTIC TARGET}

As mentioned above, different Reelin fragments are altered in neuropsychiatric and degenerative diseases. These alterations 
may be an indication of disruption in Reelin processing and may be useful in identifying biomarkers for disease states. Reelin has been shown to be sequestered by $\mathrm{A} \beta$ plaques in an age-dependent manner (Knuesel et al., 2009; Doehner and Knuesel, 2010; Kocherhans et al., 2010; Stranahan et al., 2011). Removal of Reelin from the synapse can alter many Reelindependent functions, causing abnormal cellular migration, dendritic morphology atrophy and deficits in synaptic plasticity (Herz and Chen, 2006; Rogers and Weeber, 2008; Bu, 2009). Given the progressive memory decline seen in $\mathrm{AD}$ patients, it is possible that the sequestering of Reelin by the amyloid plaques can alter its normal regulation via cleavage mechanisms and its normal enhancement of learning and memory. It is interesting to note that crossing a transgenic mouse that overexpresses Reelin with an AD mouse model protects from amyloid plaque formation and rescues learning and memory deficits when compared to the $\mathrm{AD}$ mice (Pujadas et al., 2014), while decreasing Reelin in AD models accelerates plaque formation and increases tau hyperphosphorylation (Kocherhans et al., 2010). Interestingly, a novel inducible Reelin knockout mouse line has revealed that adult knockdown of Reelin expression results in no discernable differences in normal learning and memory and actually enhances late LTP (LaneDonovan et al., 2015). When these Reelin knockdown mice were crossed with Tg2576 AD mice they did not cause an increase $A \beta$ pathology; however, these mice showed poorer learning in the hidden platform water maze and deficits in the $24 \mathrm{~h}$ probe test when compared to controls (Lane-Donovan et al., 2015). These results support the importance of Reelin signaling in normal cognitive function and shows that a loss of Reelin signaling in an $\mathrm{AD}$ mouse model increases cognitive dysfunction.

\section{REFERENCES}

Alcantara, S., Ruiz, M., D’Arcangelo, G., Ezan, F., de Lecea, L., Curran, T., et al. (1998). Regional and cellular patterns of reelin mRNA expression in the forebrain of the developing and adult mouse. J. Neurosci. 18, 7779-7799.

Beffert, U., Morfini, G., Bock, H. H., Reyna, H., Brady, S. T., and Herz, J. (2002). Reelin-mediated signaling locally regulates protein kinase B/Akt and glycogen synthase kinase 3beta. J. Biol. Chem. 277, 49958-49964. doi: 10.1074/jbc. m209205200

Beffert, U., Weeber, E. J., Durudas, A., Qiu, S., Masiulis, I., Sweatt, J. D., et al. (2005). Modulation of synaptic plasticity and memory by Reelin involves differential splicing of the lipoprotein receptor Apoer2. Neuron 47, 567-579. doi: 10.1016/j.neuron.2005.07.007

Beffert, U., Weeber, E. J., Morfini, G., Ko, J., Brady, S. T., Tsai, L. H., et al. (2004). Reelin and cyclin-dependent kinase 5-dependent signals cooperate in regulating neuronal migration and synaptic transmission. J. Neurosci. 24, 1897-1906. doi: 10.1523/JNEUROSCI.4084-03.2004

Botella-López, A., Burgaya, F., Gavín, R., García-Ayllón, M. S., Gómez-Tortosa, E., Peña-Casanova, J., et al. (2006). Reelin expression and glycosylation patterns are altered in Alzheimer's disease. Proc. Natl. Acad. Sci. US A 103, 5573-5578. doi: 10.1073/pnas.0601279103

Bu, G. (2009). Apolipoprotein E and its receptors in Alzheimer's disease: pathways, pathogenesis and therapy. Nat. Rev. Neurosci. 10, 333-344. doi: 10. 1038/nrn2620

Burrell, T. C., Divekar, S. D., Weeber, E. J., and Rebeck, G. W. (2014). Fyn tyrosine kinase increases Apolipoprotein E receptor 2 levels and phosphorylation. PLoS One 9:e110845. doi: 10.1371/journal.pone.0110845
Introduction of exogenous Reelin into the brain can have surprisingly profound effects on synaptic plasticity and cognition. Hippocampal injection(s) of Reelin and its fragments has demonstrated significant improvements in models of Reelin deficiency (Rogers et al., 2013), Angelman syndrome (Hethorn et al., 2015), and schizophrenia (Ishii et al., 2015). Remarkably, exogenous Reelin also enhanced learning and memory as well as increased synaptic plasticity in wild-type mice (Rogers et al., 2011). Thus, therapeutic approaches to promoting Reelin signaling could be useful in protecting synapse function and survival in a range of disorders. This work would require a better understanding of which domains of Reelin are necessary for the regulated Reelin signaling, and assays for examining whether new Reelin-based therapies promote receptor clustering, intracellular signaling, synapse stabilization, and neuronal protection. Although more work is required to fully understand the function of each of these Reelin fragments, the current research points to a therapeutic potential for altering specific Reelin fragments in treating neuronal dysfunction and cognitive deficits in neurodegenerative and neuropsychiatric disorders.

\section{AUTHOR CONTRIBUTIONS}

ALL wrote the review and generated the figures. EJW and GWR edited the content and structure of the review. Each author contributed ideas of topics for inclusion.

\section{ACKNOWLEDGMENTS}

This work was supported by R01 AG035379-05 for EJW and GWR.

Chen, Y., Beffert, U., Ertunc, M., Tang, T. S., Kavalali, E. T., Bezprozvanny, I., et al. (2005). Reelin modulates NMDA receptor activity in cortical neurons. J. Neurosci. 25, 8209-8216. doi: 10.1523/JNEUROSCI.1951-05.2005

Chen, M. L., Chen, S. Y., Huang, C. H., and Chen, C. H. (2002). Identification of a single nucleotide polymorphism at the $5^{\prime}$ promoter region of human reelin gene and association study with schizophrenia. Mol. Psychiatry 7, 447-448. doi: 10. 1038/sj.mp.4001026

Chin, J., Massaro, C. M., Palop, J. J., Thwin, M. T., Yu, G. Q., Bien-Ly, N., et al. (2007). Reelin depletion in the entorhinal cortex of human amyloid precursor protein transgenic mice and humans with Alzheimer's disease. J. Neurosci. 27, 2727-2733. doi: 10.1523/JNEUROSCI.3758-06.2007

Cuchillo-Ibáñez, I., Balmaceda, V., Botella-López, A., Rabano, A., Avila, J., and Sáez-Valero, J. (2013). Beta-amyloid impairs reelin signaling. PLoS One 8:e72297. doi: 10.1371/journal.pone.0072297

D’Arcangelo, G., Homayouni, R., Keshvara, L., Rice, D. S., Sheldon, M., and Curran, T. (1999). Reelin is a ligand for lipoprotein receptors. Neuron 24, 471-479. doi: 10.1016/s0896-6273(00)80860-0

D’Arcangelo, G., Nakajima, K., Miyata, T., Ogawa, M., Mikoshiba, K., and Curran, T. (1997). Reelin is a secreted glycoprotein recognized by the CR-50 monoclonal antibody. J. Neurosci. 17, 23-31.

de Bergeyck, V., Nakajima, K., Lambert de Rouvroit, C., Naerhuyzen, B., Goffinet, A. M., Miyata, T., et al. (1997). A truncated Reelin protein is produced but not secreted in the 'Orleans' reeler mutation (Reln[rl-Orl]). Brain Res. Mol. Brain Res. 50, 85-90. doi: 10.1016/s0169-328x(97)00166-6

Del Río, J. A., Heimrich, B., Borrell, V., Förster, E., Drakew, A., Alcántara, S., et al. (1997). A role for Cajal-Retzius cells and reelin in the development of hippocampal connections. Nature 385, 70-74. doi: 10.1038/385070a0 
Divekar, S. D., Burrell, T. C., Lee, J. E., Weeber, E. J., and Rebeck, G. W. (2014). Ligand-induced homotypic and heterotypic clustering of Apolipoprotein E receptor 2. J. Biol. Chem. 289, 15894-15903. doi: 10.1074/jbc.M113.537548

Doehner, J., and Knuesel, I. (2010). Reelin-mediated signaling during normal and pathological forms of aging. Aging Dis. 1, 12-29.

Drakew, A., Deller, T., Heimrich, B., Gebhardt, C., Del Turco, D., Tielsch, A., et al. (2002). Dentate granule cells in reeler mutants and VLDLR and ApoER2 knockout mice. Exp. Neurol. 176, 12-24. doi: 10.1006/exnr.2002.7918

Dulabon, L., Olson, E. C., Taglienti, M. G., Eisenhuth, S., McGrath, B., Walsh, C. A., et al. (2000). Reelin binds alpha3betal integrin and inhibits neuronal migration. Neuron 27, 33-44. doi: 10.1016/s0896-6273(00) 00007-6

Durakoglugil, M. S., Chen, Y., White, C. L., Kavalali, E. T., and Herz, J. (2009). Reelin signaling antagonizes $\beta$-amyloid at the synapse. Proc. Natl. Acad. Sci. U S A 106, 15938-15943. doi: 10.1073/pnas.0908176106

Dutta, S., Gangopadhyay, P. K., Sinha, S., Chatterjee, A., Ghosh, S., and Rajamma, U. (2011). An association analysis of Reelin gene (RELN) polymorphisms with childhood epilepsy in eastern Indian population from West Bengal. Cell. Mol. Neurobiol. 31, 45-56. doi: 10.1007/s10571-0109551-7

Fatemi, S. H. (2005). Reelin glycoprotein in autism and schizophrenia. Int. Rev. Neurobiol. 71, 179-187. doi: 10.1016/s0074-7742(05)71008-4

Fatemi, S. H., Earle, J. A., and McMenomy, T. (2000). Reduction in Reelin immunoreactivity in hippocampus of subjects with schizophrenia, bipolar disorder and major depression. Mol. Psychiatry 5, 654-663, 571. doi: 10.1038/sj. mp.4000783

Fatemi, S. H., Kroll, J. L., and Stary, J. M. (2001). Altered levels of Reelin and its isoforms in schizophrenia and mood disorders. Neuroreport 12, 3209-3215. doi: 10.1097/00001756-200110290-00014

Fatemi, S. H., Snow, A. V., Stary, J. M., Araghi-Niknam, M., Reutiman, T. J., Lee, S., et al. (2005). Reelin signaling is impaired in autism. Biol. Psychiatry 57, 777-787. doi: 10.1016/j.biopsych.2004.12.018

Fenton, E. Y., Fournier, N. M., Lussier, A. L., Romay-Tallon, R., Caruncho, H. J., and Kalynchuk, L. E. (2015). Imipramine protects against the deleterious effects of chronic corticosterone on depression-like behavior, hippocampal reelin expression and neuronal maturation. Prog. Neuropsychopharmacol. Biol. Psychiatry 60, 52-59. doi: 10.1016/j.pnpbp.2015.02.001

Fournier, N. M., Andersen, D. R., Botterill, J. J., Sterner, E. Y., Lussier, A. L., Caruncho, H. J., et al. (2010). The effect of amygdala kindling on hippocampal neurogenesis coincides with decreased reelin and DISC1 expression in the adult dentate gyrus. Hippocampus 20, 659-671. doi: 10.1002/hipo.20653

Frotscher, M. (1998). Cajal-Retzius cells, Reelin and the formation of layers. Curr. Opin. Neurobiol. 8, 570-575. doi: 10.1016/s0959-4388(98)80082-2

Guidotti, A., Auta, J., Davis, J. M., Di-Giorgi-Gerevini, V., Dwivedi, Y., Grayson, D. R., et al. (2000). Decrease in reelin and glutamic acid decarboxylase67 (GAD67) expression in schizophrenia and bipolar disorder: a postmortem brain study. Arch. Gen. Psychiatry 57, 1061-1069. doi: 10. 1001/archpsyc.57.11.1061

Haas, C. A., and Frotscher, M. (2010). Reelin deficiency causes granule cell dispersion in epilepsy. Exp. Brain Res. 200, 141-149. doi: 10.1007/s00221-0091948-5

Herring, A., Donath, A., Steiner, K. M., Widera, M. P., Hamzehian, S., Kanakis, D., et al. (2012). Reelin depletion is an early phenomenon of Alzheimer's pathology. J. Alzheimers Dis. 30, 963-979. doi: 10.3233/JAD-2012-112069

Herz, J., and Chen, Y. (2006). Reelin, lipoprotein receptors and synaptic plasticity. Nat. Rev. Neurosci. 7, 850-859. doi: 10.1038/nrn2009

Hethorn, W. R., Ciarlone, S. L., Filonova, I., Rogers, J. T., Aguirre, D., Ramirez, R. A., et al. (2015). Reelin supplementation recovers synaptic plasticity and cognitive deficits in a mouse model for Angelman syndrome. Eur. J. Neurosci. 41, 1372-1380. doi: 10.1111/ejn.12893

Hiesberger, T., Trommsdorff, M., Howell, B. W., Goffinet, A., Mumby, M. C., Cooper, J. A., et al. (1999). Direct binding of Reelin to VLDL receptor and ApoE receptor 2 induces tyrosine phosphorylation of disabled-1 and modulates tau phosphorylation. Neuron 24, 481-489. doi: 10.1016/s0896-6273(00) 80861-2

Hirota, Y., Kubo, K., Katayama, K., Honda, T., Fujino, T., Yamamoto, T. T., et al. (2015). Reelin receptors ApoER2 and VLDLR are expressed in distinct spatiotemporal patterns in developing mouse cerebral cortex. J. Comp. Neurol. 523, 463-478. doi: 10.1002/cne.23691
Hisanaga, A., Morishita, S., Suzuki, K., Sasaki, K., Koie, M., Kohno, T., et al. (2012). A disintegrin and metalloproteinase with thrombospondin motifs 4 (ADAMTS-4) cleaves Reelin in an isoform-dependent manner. FEBS Lett. 586, 3349-3353. doi: 10.1016/j.febslet.2012.07.017

Hoareau, C., Borrell, V., Soriano, E., Krebs, M. O., Prochiantz, A., and Allinquant, B. (2008). Amyloid precursor protein cytoplasmic domain antagonizes Reelin neurite outgrowth inhibition of hippocampal neurons. Neurobiol. Aging 29, 542-553. doi: 10.1016/j.neurobiolaging.2006.11.012

Hoe, H. S., Lee, K. J., Carney, R. S., Lee, J., Markova, A., Lee, J. Y., et al. (2009). Interaction of reelin with amyloid precursor protein promotes neurite outgrowth. J. Neurosci. 29, 7459-7473. doi: 10.1523/JNEUROSCI.4872-08.2009

Hoe, H. S., Tran, T. S., Matsuoka, Y., Howell, B. W., and Rebeck, G. W. (2006). DAB1 and Reelin effects on amyloid precursor protein and ApoE receptor 2 trafficking and processing. J. Biol. Chem. 281, 35176-35185. doi: 10.1074/jbc. m602162200

Howell, B. W., Gertler, F. B., and Cooper, J. A. (1997a). Mouse disabled (mDab1): a Src binding protein implicated in neuronal development. EMBO J. 16, 121-132. doi: 10.1093/emboj/16.1.121

Howell, B. W., Hawkes, R., Soriano, P., and Cooper, J. A. (1997b). Neuronal position in the developing brain is regulated by mouse disabled-1. Nature 389, 733-737. doi: 10.1038/39607

Ishii, K., Nagai, T., Hirota, Y., Noda, M., Nabeshima, T., Yamada, K., et al. (2015). Reelin has a preventive effect on phencyclidine-induced cognitive and sensorymotor gating deficits. Neurosci. Res. 96, 30-36. doi: 10.1016/j.neures.2014. 12.013

Jossin, Y., Gui, L., and Goffinet, A. M. (2007). Processing of Reelin by embryonic neurons is important for function in tissue but not in dissociated cultured neurons. J. Neurosci. 27, 4243-4252. doi: 10.1523/jneurosci.0023-07.2007

Jossin, Y., Ignatova, N., Hiesberger, T., Herz, J., Lambert de Rouvroit, C., and Goffinet, A. M. (2004). The central fragment of Reelin, generated by proteolytic processing in vivo, is critical to its function during cortical plate development. J. Neurosci. 24, 514-521. doi: 10.1523/jneurosci.3408-03.2004

Kaneko, Y., Sullivan, R., Dailey, T., Vale, F. L., Tajiri, N., and Borlongan, C. V. (2016). Kainic acid-induced golgi complex fragmentation/dispersal shifts the proteolysis of reelin in primary rat neuronal cells: an in vitro model of early stage epilepsy. Mol. Neurobiol. 53, 1874-1883. doi: 10.1007/s12035-015-9126-1

Karim, S., Mirza, Z., Ansari, S. A., Rasool, M., Iqbal, Z., Sohrab, S. S., et al. (2014). Transcriptomics study of neurodegenerative disease: emphasis on synaptic dysfunction mechanism in Alzheimer's disease. CNS Neurol. Disord. Drug Targets 13, 1202-1212. doi: 10.2174/1871527313666140917113446

Klyubin, I., Walsh, D. M., Lemere, C. A., Cullen, W. K., Shankar, G. M., Betts, V., et al. (2005). Amyloid $\beta$ protein immunotherapy neutralizes $A \beta$ oligomers that disrupt synaptic plasticity in vivo. Nat. Med. 11, 556-561. doi: 10.1038/nm1234

Knable, M. B., Barci, B. M., Webster, M. J., Meador-Woodruff, J., Torrey, E. F., and Stanley Neuropathology, C. (2004). Molecular abnormalities of the hippocampus in severe psychiatric illness: postmortem findings from the stanley neuropathology consortium. Mol. Psychiatry 9, 609-620, 544. doi: 10. 1038/sj.mp.4001471

Knuesel, I., Nyffeler, M., Mormède, C., Muhia, M., Meyer, U., Pietropaolo, S., et al. (2009). Age-related accumulation of Reelin in amyloid-like deposits. Neurobiol. Aging 30, 697-716. doi: 10.1016/j.neurobiolaging.2007.08.011

Kocherhans, S., Madhusudan, A., Doehner, J., Breu, K. S., Nitsch, R. M., Fritschy, J. M., et al. (2010). Reduced Reelin expression accelerates amyloid- $\beta$ plaque formation and tau pathology in transgenic Alzheimer's disease mice. J. Neurosci. 30, 9228-9240. doi: 10.1523/JNEUROSCI.0418-10.2010

Kohno, T., Honda, T., Kubo, K., Nakano, Y., Tsuchiya, A., Murakami, T., et al. (2015). Importance of Reelin C-terminal region in the development and maintenance of the postnatal cerebral cortex and its regulation by specific proteolysis. J. Neurosci. 35, 4776-4787. doi: 10.1523/JNEUROSCI.411914.2015

Kohno, S., Kohno, T., Nakano, Y., Suzuki, K., Ishii, M., Tagami, H., et al. (2009). Mechanism and significance of specific proteolytic cleavage of Reelin. Biochem. Biophys. Res. Commun. 380, 93-97. doi: 10.1016/j.bbrc.2009.01.039

Koie, M., Okumura, K., Hisanaga, A., Kamei, T., Sasaki, K., Deng, M., et al. (2014). Cleavage within Reelin repeat 3 regulates the duration and range of signaling activity of Reelin. J. Biol. Chem. 289, 12922-12930. doi: 10.1074/jbc.M113. 536326

Kramer, P. L., Xu, H., Woltjer, R. L., Westaway, S. K., Clark, D., ErtenLyons, D., et al. (2011). Alzheimer's disease pathology in cognitively healthy 
elderly: a genome-wide study. Neurobiol. Aging 32, 2113-2122. doi: 10.1016/j. neurobiolaging.2010.01.010

Krstic, D., Rodriguez, M., and Knuesel, I. (2012). Regulated proteolytic processing of Reelin through interplay of tissue plasminogen activator (tPA), ADAMTS4, ADAMTS-5 and their modulators. PLoS One 7:e47793. doi: 10.1371/journal. pone. 0047793

Lambert de Rouvroit, C., de Bergeyck, V., Cortvrindt, C., Bar, I., Eeckhout, Y., and Goffinet, A. M. (1999). Reelin, the extracellular matrix protein deficient in reeler mutant mice, is processed by a metalloproteinase. Exp. Neurol. 156, 214-217. doi: 10.1006/exnr.1998.7007

Lane-Donovan, C., Philips, G. T., Wasser, C. R., Durakoglugil, M. S., Masiulis, I., Upadhaya, A., et al. (2015). Reelin protects against amyloid $\beta$ toxicity in vivo. Sci. Signal. 8:ra67. doi: 10.1126/scisignal.aaa6674

Lasagna-Reeves, C. A., Castillo-Carranza, D. L., Sengupta, U., Clos, A. L., Jackson, G. R., and Kayed, R. (2011). Tau oligomers impair memory and induce synaptic and mitochondrial dysfunction in wild-type mice. Mol. Neurodegener. 6:39. doi: 10.1186/1750-1326-6-39

Lasagna-Reeves, C. A., Castillo-Carranza, D. L., Sengupta, U., GuerreroMunoz, M. J., Kiritoshi, T., Neugebauer, V., et al. (2012). Alzheimer brainderived tau oligomers propagate pathology from endogenous tau. Sci. Rep. 2:700. doi: $10.1038 /$ srep00700

Lussier, A. L., Caruncho, H. J., and Kalynchuk, L. E. (2009). Repeated exposure to corticosterone, but not restraint, decreases the number of Reelin-positive cells in the adult rat hippocampus. Neurosci. Lett. 460, 170-174. doi: 10.1016/j. neulet.2009.05.050

Lussier, A. L., Lebedeva, K., Fenton, E. Y., Guskjolen, A., Caruncho, H. J., and Kalynchuk, L. E. (2013a). The progressive development of depressionlike behavior in corticosterone-treated rats is paralleled by slowed granule cell maturation and decreased reelin expression in the adult dentate gyrus. Neuropharmacology 71C, 174-183. doi: 10.1016/j.neuropharm.2013.04.012

Lussier, A. L., Romay-Tallón, R., Caruncho, H. J., and Kalynchuk, L. E. (2013b). Altered GABAergic and glutamatergic activity within the rat hippocampus and amygdala in rats subjected to repeated corticosterone administration but not restraint stress. Neuroscience 231, 38-48. doi: 10.1016/j.neuroscience.2012. 11.037

Lussier, A. L., Romay-Tallon, R., Kalynchuk, L. E., and Caruncho, H. J. (2011). Reelin as a putative vulnerability factor for depression: examining the depressogenic effects of repeated corticosterone in heterozygous reeler mice. Neuropharmacology 60, 1064-1074. doi: 10.1016/j.neuropharm.2010.09.007

Mota, S. I., Ferreira, I. L., Valero, J., Ferreiro, E., Carvalho, A. L., Oliveira, C. R., et al. (2014). Impaired Src signaling and post-synaptic actin polymerization in Alzheimer's disease mice hippocampus-linking NMDA receptors and the reelin pathway. Exp. Neurol. 261, 698-709. doi: 10.1016/j.expneurol.2014.07.023

Nagy, V., Bozdagi, O., Matynia, A., Balcerzyk, M., Okulski, P., Dzwonek, J., et al. (2006). Matrix metalloproteinase-9 is required for hippocampal latephase long-term potentiation and memory. J. Neurosci. 26, 1923-1934. doi: 10. 1523/jneurosci.4359-05.2006

Nakajima, K., Mikoshiba, K., Miyata, T., Kudo, C., and Ogawa, M. (1997). Disruption of hippocampal development in vivo by CR-50 mAb against reelin. Proc. Natl. Acad. Sci. U S A 94, 8196-8201. doi: 10.1073/pnas.94.15.8196

Nakano, Y., Kohno, T., Hibi, T., Kohno, S., Baba, A., Mikoshiba, K., et al. (2007). The extremely conserved C-terminal region of Reelin is not necessary for secretion but is required for efficient activation of downstream signaling. J. Biol. Chem. 282, 20544-20552. doi: 10.1074/jbc.m702300200

Niu, S., Renfro, A., Quattrocchi, C. C., Sheldon, M., and D'Arcangelo, G. (2004). Reelin promotes hippocampal dendrite development through the VLDLR/ApoER2-Dab1 pathway. Neuron 41, 71-84. doi: 10.1016/s08966273(03)00819-5

Niu, S., Yabut, O., and D'Arcangelo, G. (2008). The Reelin signaling pathway promotes dendritic spine development in hippocampal neurons. J. Neurosci. 28, 10339-10348. doi: 10.1523/JNEUROSCI.1917-08.2008

Nogi, T., Yasui, N., Hattori, M., Iwasaki, K., and Takagi, J. (2006). Structure of a signaling-competent reelin fragment revealed by X-ray crystallography and electron tomography. EMBO J. 25, 3675-3683. doi: 10.1038/sj.emboj.7601240

Notter, T., and Knuesel, I. (2013). Reelin immunoreactivity in neuritic varicosities in the human hippocampal formation of non-demented subjects and Alzheimer's disease patients. Acta Neuropathol. Commun. 1:27. doi: 10. 1186/2051-5960-1-27
Ogawa, M., Miyata, T., Nakajima, K., Yagyu, K., Seike, M., Ikenaka, K., et al. (1995). The reeler gene-associated antigen on Cajal-Retzius neurons is a crucial molecule for laminar organization of cortical neurons. Neuron 14, 899-912. doi: 10.1016/0896-6273(95)90329-1

Ohkubo, N., Lee, Y. D., Morishima, A., Terashima, T., Kikkawa, S., Tohyama, M., et al. (2003). Apolipoprotein E and Reelin ligands modulate tau phosphorylation through an Apolipoprotein E receptor/disabled-1/glycogen synthase kinase-3beta cascade. FASEB J. 17, 295-297. doi: 10.1096/fj.020434fje

Pesold, C., Impagnatiello, F., Pisu, M. G., Uzunov, D. P., Costa, E., Guidotti, A., et al. (1998). Reelin is preferentially expressed in neurons synthesizing gammaaminobutyric acid in cortex and hippocampus of adult rats. Proc. Natl. Acad. Sci. U S A 95, 3221-3226. doi: 10.1073/pnas.95.6.3221

Pesold, C., Liu, W. S., Guidotti, A., Costa, E., and Caruncho, H. J. (1999). Cortical bitufted, horizontal and Martinotti cells preferentially express and secrete Reelin into perineuronal nets, nonsynaptically modulating gene expression. Proc. Natl. Acad. Sci. U S A 96, 3217-3222. doi: 10.1073/pnas.96.6.3217

Pujadas, L., Gruart, A., Bosch, C., Delgado, L., Teixeira, C. M., Rossi, D., et al. (2010). Reelin regulates postnatal neurogenesis and enhances spine hypertrophy and long-term potentiation. J. Neurosci. 30, 4636-4649. doi: 10. 1523/JNEUROSCI.5284-09.2010

Pujadas, L., Rossi, D., Andres, R., Teixeira, C. M., Serra-Vidal, B., Parcerisas, A., et al. (2014). Reelin delays amyloid-beta fibril formation and rescues cognitive deficits in a model of Alzheimer's disease. Nat. Commun. 5:3443. doi: 10. 1038/ncomms4443

Qiu, S., Korwek, K. M., Pratt-Davis, A. R., Peters, M., Bergman, M. Y., and Weeber, E. J. (2006a). Cognitive disruption and altered hippocampus synaptic function in Reelin haploinsufficient mice. Neurobiol. Learn. Mem. 85, 228-242. doi: 10.1016/j.nlm.2005.11.001

Qiu, S., Zhao, L. F., Korwek, K. M., and Weeber, E. J. (2006b). Differential reelininduced enhancement of NMDA and AMPA receptor activity in the adult hippocampus. J. Neurosci. 26, 12943-12955. doi: 10.1523/jneurosci.2561-06. 2006

Qiu, S., and Weeber, E. J. (2007). Reelin signaling facilitates maturation of CA1 glutamatergic synapses. J. Neurophysiol. 97, 2312-2321. doi: 10.1152/jn.00869. 2006

Reddy, S. S., Connor, T. E., Weeber, E. J., and Rebeck, W. (2011). Similarities and differences in structure, expression and functions of VLDLR and ApoER2. Mol. Neurodegener. 6:30. doi: 10.1186/1750-1326-6-30

Rice, D. S., and Curran, T. (2001). Role of the reelin signaling pathway in central nervous system development. Annu. Rev. Neurosci. 24, 1005-1039. doi: 10. 1146/annurev.neuro.24.1.1005

Rice, H. C., Young-Pearse, T. L., and Selkoe, D. J. (2013). Systematic evaluation of candidate ligands regulating ectodomain shedding of amyloid precursor protein. Biochemistry 52, 3264-3277. doi: 10.1021/bi400165f

Rogers, J. T., Rusiana, I., Trotter, J., Zhao, L., Donaldson, E., Pak, D. T., et al. (2011). Reelin supplementation enhances cognitive ability, synaptic plasticity and dendritic spine density. Learn. Mem. 18, 558-564. doi: 10.1101/lm. 2153511

Rogers, J. T., and Weeber, E. J. (2008). Reelin and ApoE actions on signal transduction, synaptic function and memory formation. Neuron Glia Biol. 4 , 259-270. doi: 10.1017/s1740925x09990184

Rogers, J. T., Zhao, L., Trotter, J. H., Rusiana, I., Peters, M. M., Li, Q., et al. (2013). Reelin supplementation recovers sensorimotor gating, synaptic plasticity and associative learning deficits in the heterozygous reeler mouse. J. Psychopharmacol. 27, 386-395. doi: 10.1177/0269881112463468

Sáez-Valero, J., Costell, M., Sjögren, M., Andreasen, N., Blennow, K., and Luque, J. M. (2003). Altered levels of cerebrospinal fluid reelin in frontotemporal dementia and Alzheimer's disease. J. Neurosci. Res. 72, 132-136. doi: 10.1002/jnr.10554

Santacruz, K., Lewis, J., Spires, T., Paulson, J., Kotilinek, L., Ingelsson, M., et al. (2005). Tau suppression in a neurodegenerative mouse model improves memory function. Science 309, 476-481. doi: 10.1126/science.11 13694

Sato, Y., Kobayashi, D., Kohno, T., Kidani, Y., Prox, J., Becker-Pauly, C., et al. (2016). Determination of cleavage site of Reelin between its sixth and seventh repeat and contribution of meprin metalloproteases to the cleavage. J. Biochem. 159, 305-312. doi: 10.1093/jb/mvv102 
Schellenberg, G. D., and Montine, T. J. (2012). The genetics and neuropathology of Alzheimer's disease. Acta Neuropathol. 124, 305-323. doi: 10.1007/s00401012-0996-2

Selkoe, D. J. (2008). Soluble oligomers of the amyloid $\beta$-protein impair synaptic plasticity and behavior. Behav. Brain Res. 192, 106-113. doi: 10.1016/j.bbr.2008. 02.016

Sheng, M., Sabatini, B. L., and Südhof, T. C. (2012). Synapses and Alzheimer's disease. Cold Spring Harb. Perspect. Biol. 4:a005777. doi: 10.1101/cshperspect. a005777

Shipton, O. A., Leitz, J. R., Dworzak, J., Acton, C. E., Tunbridge, E. M., Denk, F., et al. (2011). Tau protein is required for amyloid $\beta$-induced impairment of hippocampal long-term potentiation. J. Neurosci. 31, 1688-1692. doi: 10. 1523/JNEUROSCI.2610-10.2011

Stranahan, A. M., Haberman, R. P., and Gallagher, M. (2011). Cognitive decline is associated with reduced reelin expression in the entorhinal cortex of aged rats. Cereb. Cortex 21, 392-400. doi: 10.1093/cercor/bhQ116

Strasser, V., Fasching, D., Hauser, C., Mayer, H., Bock, H. H., Hiesberger, T., et al. (2004). Receptor clustering is involved in Reelin signaling. Mol. Cell. Biol. 24, 1378-1386. doi: 10.1128/mcb.24.3.1378-1386.2004

Talantova, M., Sanz-Blasco, S., Zhang, X., Xia, P., Akhtar, M. W., Okamoto, S., et al. (2013). A $\beta$ induces astrocytic glutamate release, extrasynaptic NMDA receptor activation and synaptic loss. Proc. Natl. Acad. Sci. U S A 110, E2518-E2527. doi: 10.1073/pnas.1306832110

Tapia-González, S., García-Segura, L. M., Tena-Sempere, M., Frago, L. M., Castellano, J. M., Fuente-Martin, E., et al. (2011). Activation of microglia in specific hypothalamic nuclei and the cerebellum of adult rats exposed to neonatal overnutrition. J. Neuroendocrinol. 23, 365-370. doi: 10.1111/j.13652826.2011.02113.x

Teixeira, C. M., Kron, M. M., Masachs, N., Zhang, H., Lagace, D. C., Martinez, A., et al. (2012). Cell-autonomous inactivation of the Reelin pathway impairs adult neurogenesis in the hippocampus. J. Neurosci. 32, 12051-12065. doi: 10. 1523/jneurosci.1857-12.2012

Teixeira, C. M., Martin, E. D., Sahun, I., Masachs, N., Pujadas, L., Corvelo, A., et al. (2011). Overexpression of Reelin prevents the manifestation of behavioral phenotypes related to schizophrenia and bipolar disorder. Neuropsychopharmacology 36, 2395-2405. doi: 10.1038/npp.2011.153

Tinnes, S., Ringwald, J., and Haas, C. A. (2013). TIMP-1 inhibits the proteolytic processing of Reelin in experimental epilepsy. FASEB J. 27, 2542-2552. doi: 10. 1096/fj.12-224899

Tinnes, S., Schäfer, M. K., Flubacher, A., Munzner, G., Frotscher, M., and Haas, C. A. (2011). Epileptiform activity interferes with proteolytic processing of Reelin required for dentate granule cell positioning. FASEB J. 25, 1002-1013. doi: 10.1096/fj.10-168294

Tissir, F., and Goffinet, A. M. (2003). Reelin and brain development. Nat. Rev. Neurosci. 4, 496-505. doi: 10.1038/nrn1113

Torrey, E. F., Barci, B. M., Webster, M. J., Bartko, J. J., Meador-Woodruff, J. H., and Knable, M. B. (2005). Neurochemical markers for schizophrenia, bipolar disorder and major depression in postmortem brains. Biol. Psychiatry 57, 252-260. doi: 10.1016/j.biopsych.2004.10.019

Trojanowski, J. Q., and Lee, V. M. (2002). The role of tau in Alzheimer's disease. Med. Clin. North Am. 86, 615-627. doi: 10.1016/S0025-7125(02) 00002-0

Trommsdorff, M., Gotthardt, M., Hiesberger, T., Shelton, J., Stockinger, W., Nimpf, J., et al. (1999). Reeler/Disabled-like disruption of neuronal migration in knockout mice lacking the VLDL receptor and ApoE receptor 2. Cell 97, 689-701. doi: 10.1016/s0092-8674(00)80782-5

Trotter, J., Lee, G. H., Kazdoba, T. M., Crowell, B., Domogauer, J., Mahoney, H. M. et al. (2013). Dab1 is required for synaptic plasticity and associative learning. J. Neurosci. 33, 15652-15668. doi: 10.1523/JNEUROSCI.201013.2013

Trotter, J. H., Lussier, A. L., Psilos, K. E., Mahoney, H. L., Sponaugle, A. E., Hoe, H. S., et al. (2014). Extracellular proteolysis of reelin by tissue plasminogen activator following synaptic potentiation. Neuroscience 274, 299-307. doi: 10. 1016/j.neuroscience.2014.05.046

Weeber, E. J., Beffert, U., Jones, C., Christian, J. M., Forster, E., Sweatt, J. D., et al. (2002). Reelin and ApoE receptors cooperate to enhance hippocampal synaptic plasticity and learning. J. Biol. Chem. 277, 39944-39952. doi: 10. 1074/jbc.m205147200

Zhao, S., Chai, X., and Frotscher, M. (2007). Balance between neurogenesis and gliogenesis in the adult hippocampus: role for Reelin. Dev. Neurosci. 29, 84-90. doi: $10.1159 / 000096213$

Conflict of Interest Statement: The authors declare that the research was conducted in the absence of any commercial or financial relationships that could be construed as a potential conflict of interest.

Copyright (c) 2016 Lussier, Weeber and Rebeck. This is an open-access article distributed under the terms of the Creative Commons Attribution License (CC BY). The use, distribution and reproduction in other forums is permitted, provided the original author(s) or licensor are credited and that the original publication in this journal is cited, in accordance with accepted academic practice. No use, distribution or reproduction is permitted which does not comply with these terms. 